\title{
Articles
}

http://dx.doi.org/10.15762/ZH.2018.56

EDMUND KIZIK

(Polish Academy of Sciences)

\section{In Gold and Silver: Panoramas of Gdańsk ON CoIns ANd Medals IN THE $17^{\mathrm{TH}}$ AND $18^{\mathrm{TH}}$ Centuries*}

Key words: Gdańsk, medallist, urban symbolism of the panorama of the city, political iconography, $17^{\text {th }}-18^{\text {th }}$ centuries

The records of the Gdańsk city treasury (kamlaria) contain an entry of 25 May 1600 informing that the painter Anton Möller the Elder (ca. $1563-1611)^{1}$ received 450 Mark as the last instalment of the fee for the painting of the panorama of Gdańsk; it was ordered the previous year and an advance had been paid. The work was commissioned by Marco Ottoboni ${ }^{2}$, the Secretary of the Republic of Venice: "Diser Stadt Conterfeiung so Anthony Muller gemachet, und $\mathrm{H}$. Marco Otobono venedischen Secretario verehret worden, darfür dem Maler gezalet uber die 50 fl., so er Anno [15]99 darauf $\mathrm{e}[\mathrm{m}]$ pfangen $-450 \mathrm{Mk}^{\prime 3}$.

This is the oldest known source mentioning a painted veduta of Gdańsk cityscape ordered by the City Council. Besides presenting Gdańsk, gifting the

* This text was written as part of the project "The celebration of power: Public ceremonies in big cities of Royal Prussia in the $16^{\text {th }}-18^{\text {th }}$ centuries" carried out in the Institute of History of the Polish Academy of Sciences (Narodowe Centrum Nauki [The National Science Centre. Poland], Dec: 2015/17/B/HS3/00169). I use here fragments of my article written for the Historical Atlas of Gdańsk, which has not been published yet, supervised by Wiesław Długokęcki from University of Gdańsk: Edmund KızıK, Gdańskie weduty oraz sceny uliczne z 2 połowy XVI do pocz. XIX wieku [in print].

${ }^{1}$ See more about the artist: Jacek TYLICKI, Rysunek gdański ostatniej ćwierci XVI i pierwszej połowy XVII wieku, Torun 2005, pp. 177-212.

${ }^{2}$ Marco Ottoboni (1554-1646), a member of the influential Venetian family and the father of the future pope Clement VIII, in the name of Signoria he carried out many diplomatic trips. Ottoboni in the years 1590-1591 negotiated the purchase of crops in Gdańsk, see: Milja van Tielhof, The 'Mother of All Trades'. The Baltic Grain Trade in Amsterdam from the Late $16^{\text {th }}$ to the Early $19^{\text {th }}$ Century, Leiden-Boston-Köln 2002, pp. 207-212.

${ }^{3}$ Archiwum Państwowe w Gdańsku [State Archives in Gdańsk], 300, 12/28, p. 137; Janusz Pałubicki quotes the source note, see: idem, Malarze Gdańscy. Malarze, szklarze, rysownicy i rytownicy w okresie nowożytnym w gdańskich materiałach archiwalnych, vol. 2, Gdańsk 2009, p. 542. 
representative of the Venetian authorities with such a spectacular work aimed at maintaining the relations established between these two distant city republics ${ }^{4}$. The interest of mighty Venice flattered the Gdańsk elites, but high transport costs and tariffs had a sobering effect, and after a dozen or so years they put an end to those daring plans. Unfortunately, this spectacular painting has not survived, which is a great loss to the studies of the craft of painting in modern Gdańsk - not only because despite appearances, the economic and political importance of the city in the $16^{\text {th }}$ century was not sufficiently reflected in art, but also due to the fact that Möller's painting constituted a conscious reference to laudes urbium, classical literary descriptions of cities and places deserving universal admiration and respect ${ }^{5}$. Soon, the idea of creating Gdańsk cityscapes would spawn numerous imitators, and the characteristic view of a port city would be recorded not only by artists on canvas and paper, but also by medallists in various techniques ${ }^{6}$.

${ }^{4}$ The older literature of the subject has not lost its significance: Theodor Hirsch, Ueber den Handelsverkehr Danzigs mit den Italienischen Staaten zu Ende des 16. Jahrhunderts, Preussische Provinzial-Blätter, Bd. 4: 1847, pp. 97-114, 217-241; Ludwik BoRATyŃski, Przyczynek do dziejów pierwszych stosunków handlowych Gdańska $z$ Włochami, a w szczególności $z$ Wenecya, Rozprawy Wydziału Historyczno-Filozoficznego Akademii Umiejętności, vol. 51: 1908, pp. 219-277. See also: Edmund CieśLAK, Korespondencja Marco Ottoboni, wysłannika Wenecji do Gdańska $z$ lat 1590-1591, Sprawozdania Gdańskiego Towarzystwa Naukowego, vol. 6: 1980 , pp. $75-76$.

${ }^{5}$ See Edmund KotARSKI, Gdańska poezja okolicznościowa XVII wieku, Gdańsk 1993, p. 287.

${ }^{6}$ See general reviews of Gdańsk's iconography: Otto GüNTHER, Die älteste Sammlung von Danziger Ansichten, Zeitschrift des Westpreussischen Geschichtsvereins, Bd. 41: 1900, pp. 189-196; Friedrich Schwarz, Danzig im Bilde. Verzeichnis der in der Danziger Stadtbibliothek vorhandenen bildlichen Darstellungen zur Geschichte und Topographie von Danzig und Umgegend, Danzig 1913; Willi Drost, Das Stadtbild Danzigs in der Kunst, Ostdeutsche Monatshefte, Bd. 11: 1930, no. 4, pp. 209-217; Hans Meyer, Die Danziger Stadtvedute in ihrer künstlerischen Würdigung. Ein Beitrag zur Geschichte der Vedute, Königsberg in Pr. 1934; Otto KLoEPPEL, Das Stadtbild von Danzig in den drei Jahrhunderten seiner großen Geschichte, Danzig 1937; Friedrich Schwarz, Das Deutsche Danzig im Wandel der Zeit in 60 Bildern, Danzig 1927; Danuta IDZIAK, Dawny Gdańsk w rycinach XVI-XVIII w. Katalog wystawy Muzeum Pomorskiego w Gdańsku, Gdańsk 1969; Irena Rembowska, Panorama Gdańska w grafice XVI-XVIII wieku, Zeszyty Naukowe Wydziału Humanistycznego Uniwersytetu Gdańskiego. Historia, vol. 1: 1972, pp. 39-55; Zofia JaKRZEWSKA-ŚNieżKo, Gdańsk w dawnych rycinach, Wrocław 1980; Kazimierz Kozica, Janusz Pezda, Dantiscum Emporium Totius Europae Celeberrimum. Gdańsk i Bałtyk na mapach, widokach oraz dokumentach ze zbiorów Tomasza Niewodniczańskiego. Katalog wystawy, Gdańsk 2004 (further cit. Dantiscum Emporium). See for the $18^{\text {th }}$ century: Edmund KIZIK, Danziger Veduten und Straßenszenen aus dem 18. Jahrhundert, Vana Tallinn, vol. 21: 2010, pp. 140-159; Portret ponad wszystko. Jacob Wessel i jego wiek. Sztuka Gdańska XVIII wieku, ed. Anna Mosingiewicz, Dariusz Kaczor, Gdańsk 2005; Heinz Lingenberg, Die baugeschichtliche Entwicklung Danzigs im Spiegel seiner ältesten Veduten (bis zum Anfang des 17. Jahrhunderts) (mit einer Falttafel), [in:] Lüneburger Beiträge zur Vedutenforschung, ed. Eckhard JäGER, Lüneburg 1983, pp. 85-96. 
The focus of this text are modern panoramas of Gdańsk on $17^{\text {th }}$ and $18^{\text {th }}$ century medals as a tool of self-presentation and self-identification of the city elites. Naturally, this was only one of many forms of visual political propaganda practised by the City Council of modern Gdańsk ${ }^{7}$. However, rarely was the image of a rich city so clearly connected with gold and silver as well as with the specific form of a diplomatic gift.

Although panel painting flourished quite well in Gdańsk during the late Middle Ages (mid-15 $5^{\text {th }}$ to mid- $16^{\text {th }}$ century), realistic representations of the city or its part from that time either did not exist or have not survived. Buildings and streets presented in Gdańsk medieval paintings are only an ideal image of a city as such, or perhaps Jerusalem or any other city from the Bible or hagiographies, without a distinct relation to the contemporary Gdańsk ${ }^{8}$. It is surprising, as there is no lack of paintings that quite truthfully reflect certain realities of the period'. However, apart from the hazy silhouette of Gdańsk somewhere on the horizon line of the painting Oblężenie Malborka ('The Siege of Marienburg', before 1488) ${ }^{10}$, the earliest known and documented attempt at representing the city is the coloured drawing in the Prussian Chronicle by Heinrich von Rheden, dated 1533. The picture, known from several copies, accompanied the description of the siege of Gdańsk by the Brandenburg troops in 1307. It has been discussed in the literature on the subject, so let me remind here that it presents an alleged fragment of a line of buildings seen from the Motława [Mottlau] River ${ }^{11}$. The first of realistic panoramic vedute of Gdańsk

${ }^{7}$ Edmund Kızıк, Prezenty w polityce Gdańska $w$ XVII-XVIII wieku, [in:] Prusy i Inflanty między średniowieczem a nowożytnością. Państwo - społeczeństwo - kultura, ed. Bogusław DyBAś, Dariusz MakiŁŁa, Toruń 2003, pp. 105-116.

${ }^{8}$ For example, the presentation of streets and houses in the pictures of the plaque of Ten commandments or in the Altar of St. Barbara from the St. Mary's Church in Gdańsk.

${ }^{9}$ For example, the picture Oblężenie Malborka ['The siege of Marienburg'] (prior to 1488). Aspects of everyday life and material culture in Gdańsk painting from the end of the $15^{\text {th }}$ century to the mid- $16^{\text {th }}$ century has not been researched thoroughly yet. Most of research assumptions of Adam S. Labuda remain valid, see: Adam S. LABudA, Malarstwo tablicowe w Gdańsku w 2 poł. $X V w$. Warszawa 1979, p. 114.

${ }^{10}$ Apart from the inscription, the panorama of Gdańsk may be identified thanks to the characteristic towers of St. Mary's Church and the Main City Hall of Gdańsk. The interpretations of the possible architecture along the bank of Motława [Mottlau] River in the picture Okręt Kościoła ['The Ship of the Church'] is a mere conjecture. See: A. S. LABUdA, op.cit., pp. 115-120.

${ }^{11}$ See: Otto Günther, Ein Stückchen Danzig im Jahre 1553, Mitteilungen des Westpreußischen Geschichtsvereins, Jg. 11: 1912, Nr. 4, pp. 62-65; repr. in: Hans Bernhard MEYER, Danziger Stadtveduten, Unser Danzig, Bd. 33: 1981, Nr. 4, pp. 10-12 (here: p. 10); generally about drawings in the book by Heinrich Rheden: Udo ARNOLD, Studien zur preussischen Historiographie des 16. Jahrhunderts, Bonn 1967. See the copy of Preußische Chronik in the collection of Staatsbibliothek Berlin, Ms. boruss. fol. 176 available online: http://digital.staatsbibliothek-berlin.de/ werkansicht?PPN=PPN660778696\&PHYSID=PHYS_0005\&DMDID = [Accessed 1.06.2108]. 
was created just before 1573 as a drawing - or maybe a series of drawings that served as a model for an engraver. It was published in 1575 and again the following year as the $46^{\text {th }}$ illustration in the second part of the six-volume atlas by Georg Braun (text author) and Frans Hogenberg (copperplate engraver), titled Civitates orbis terrarum and published in the years $1572-1617^{12}$. The work of Braun and Hogenberg was created as an answer to readers' demand - that has been growing since the mid $-16^{\text {th }}$ century - for books containing cityscapes, cartographic presentations as well as annotated plans of "all the states and cities" of the contemporary world. Thus the engraving of Gdańsk was accompanied by a suitable key, describing individual buildings, gates and areas, as well as a terse description of the city itself. Hogenberg's copperplate engraving, coloured in places with watercolours, presents a north-western view of Gdańsk, from Góra Gradowa Hill. This characteristic and quite natural view from high moraine hills surrounding the city would be frequently copied from then on until the early $19^{\text {th }}$ century, contributing to the topos of the Gdańsk veduta. The view from the north-west would be sometimes replaced by that from the south-east, from Biskupia Górka. The cityscape would be accompanied by a characteristic group of burghers - men and women from Gdańsk representing different social strata - placed in the foreground. Such a combination of a cityscape with a presentation of figures in regional costumes was reflected at the end of the $16^{\text {th }}$ century in popular costume books, i.e. Trachtenbücher ${ }^{13}$.

The unquestionable innovativeness of such book illustrations captured the imagination of both artists and their patrons - the city authorities - and spawned a multitude of local imitators across Northern Europe. Also the artists of Gdańsk succumbed to this fashion, responding to the growing popular demand. Their creations included authentic cityscapes created from the 1590s

${ }^{12}$ Georg Braun, Frans Hogenberg, Civitates orbis terrarum, [vol. 2], De praecipuis totius universi urbibus liber secundus, Coloniae Agripinae 1575, and in the German edition: Beschreibung und Contrafactur von den vornemsten Stetten der Welt, Köln 1576. The copy preserved in the collection of the Gdańsk Library of the Polish Academy of Sciences (Bibl. Gd. PAN), see the literature: Aurea Porta, cat. nr V.1, p. 140; Dantiscum emporium, cat. G 95/1, pp. 247-249; Zofia JAKRZEWSKA-ŚNIEŻKo, Architektura i umocnienia obronne Gdańska w 3 ćw. XVI w. na podstawie ryciny F. Hogenberga $z 1573$ r., Biuletyn Historii Sztuki, vol. 1: 1972, pp. 36-44. The plaques with the engravings of the cities available online: http://historic-cities.huji.ac.il/mapmakers/ braun hogenberg.html [Accessed 9.03.2018].

${ }^{13}$ Great popularity was won by Trachtenbuch written by Hans Weigel Habitus praecipuorum populorum, tam virorum quam foeminarum singulari arte depicti. Trachtenbuch Trachtenbuch, Darin fast allerley vnd der fürnembsten Nationen die heutigs tags bekandt sein Kleidungen... abgerissen sein..., Nürnberg 1577; see: Magdalena Mielnik, Stateczne matrony i cnotliwe panny, czyli „Księga ubiorów gdańskich” Antona Möllera w kontekście tradycji „Trachtenbüchern”, Quart, 2008, no. 3, pp. 20-40; Edmund KIZIK, Ubiory gdańskich mieszczek w końcu XVI i w pierwszej połowie XVII wieku, Rocznik Gdański, vol. 67-68: 2007-2008, pp. 17-31. 
to 1630 s, characterized not only by original approaches but also by far greater precision and accuracy in representing the details of their home citythan the Braun-Hogenberg panorama had. However, despite their creators' perfection, the reach of the engravings was relatively limited. This was the result of the activities of a Frankfurt publisher Matthäus Merian the Elder (1593-1650). Merian's aim was to create an album that would be a continuation of Civitates orbis terrarum, yet one with much better quality and more precise descriptions. Merian's work Topographia Germaniae (1642-1688), continued by his sons and heirs Matthäus and Caspar, comprises the total of 30 volumes and more than 2142 views and plans as well as descriptions of towns in Germany and other countries ${ }^{14}$.

The cityscapes of Prussian and Pomeranian towns included also a view of Gdańsk itself ("Dantiscum / Dantzig"), published in the volume from $1652^{15}$. The engraving, however, had been created at least ten years earlier - in 1641 and it served as an illustration in the second edition of the history of the Hanseatic cities by Johann Angelius von Werdenhagen $\left(1^{\text {st }} \text { edition } 1631\right)^{16}$. Merian used this engraving also in other books reprinted by his house, such as Newe Archontologia Cosmica by Johann L. Gottfried (1649), which in turn was a reworking of Pierre d'Avita's 1638 book $^{17}$. Merian was not an original creator: he used the panorama (from 1625) by Vischer the Younger (Piscator) ${ }^{18}$, available from booksellers, which in turn was a miniaturized copy of the 1617 work by a Gdańsk artist Aegidius Dickman. Despite its flaws and anachronisms, high circulation and good distribution made the panorama of Gdańsk based on Merian's engraving the model frequently replicated and copied until the early $19^{\text {th }}$ century. This proves that despite Gdańsk's power, the importance

${ }^{14}$ Lucas H. Wüthrich, Das druckgraphische Werk von Matthäus Merian, vol. 1-2, Basel 1966; idem, Das druckgraphische Werk von Matthäus Merian, vol. 4, Hamburg 1996.

${ }^{15}$ Matthäus Merian, Topographia Electoratus Brandenburgici et Ducatus Pomeraniae, (Topographia Germaniae, vol. 16), Frankfurt am Main 1652, pp. 14-22. Available online: http:// de.wikisource.org/wiki/Topographia_Electoratus_Brandenburgici_et_Ducatus_Pomeraniae [Accessed 10.10.2018].

${ }^{16}$ Johann A. von Werdenhagen, De rebuspublicis Hanseaticis earumque nobili confederation, Frankfurt am Main 1641. See the literature of the subject: Dantiscum Emporium, p. 268, cat. nr G 101.

${ }^{17}$ Pierre D’Avity, Neuwe Archontologia Cosmica, das ist Beschreibung aller Käyserthumben, Königreichen und Republicken der gantzen Welt, die keinen Höhern erkennen..., Franckfurt am Mayn 1638. The work from Merian's publishining office does not include the panorama of Gdańsk (from among Prussian towns - only Elbląg, after p. 327) available online: https://www. sbc.org.pl/dlibra/publication/12381/edition/34314 [Accessed 15.10.2018].

${ }^{18}$ Repr. in: Z. JAKRZEWSKA-ŚNIEŻKO, Gdańsk $w$ dawnych rycinach, the pull-out after pp. 18, 20-21 (dated 1620). 
of local printers was limited and did not influence the readers' imagination on the European scale.

Yet, the local artists created truly impressive works. A monumental veduta of the city seen from Biskupia Górka is dated 1592/1593; it was printed from seven copperplates and its total dimensions were $221 \times 35.3 \mathrm{~cm}$. Only a part of the original has been preserved, but luckily a reduced-size print of the entire cityscape was made in 1916. The author of this panorama, seen from the south-western hill of Biskupia Górka and including a key describing individual buildings, was Anton Möller the Elder, mentioned in the introduction $^{19}$. The meticulously detailed work, accompanied by suitable descriptions, undoubtedly constituted the basis for the cityscape painting which left Gdańsk in 1600 with the Venetian Ottoboni. Another work that should be ascribed to Möller or artists from his circle is the axonometric view of the city consisting of 23 (?) drawings of total size $988 \times 743$, which is kept in the collection of the Krigsarkivet in Stockholm ${ }^{20}$. The work made at the scale of 1:50 ells has been ascribed in literature to Claesz Jansz Vischer or to Georg Schmer ${ }^{21}$ and dated ca. 1620. However, the architectural details and the introduction of a group of people in Gdańsk costumes typical of an earlier period allow a significant verification of the previous findings and pushing back the creation date to ca. $1600-1605^{22}$. The work can be connected not only to Möller himself but also to the surveys conducted at that time in connection with the planned construction of new fortifications ${ }^{23}$. Clearly, this unusual work was being created over a longer period of time and was ultimately left unfinished, or perhaps was

${ }^{19}$ Warhaffige Contrafactur der furtreflichen und weltberumten Sestadt Dantzig in Preussen wie dieselbe vom Bischofsberge eigentlich anzusehen ist. Da zugleich unten an alle Kirchen und furnembste Gebawe mit sonderlichen Buchstaben verzeichnet und genennet werden. In the collections of the Library in Gdańsk of the Polish Academy of Sciences, no. 6113; Lit.: Zofia JAKRZEWSKA-ŚNIEżKo, Antoniego Möllera widok Gdańska z końca XVI wieku, Libri Gedanenses, vol. 6-7: 1975, pp. 5-28; eadem, Gdańsk w dawnych rycinach, pp. 8-15; Janusz CiemnoŁońsKI, Panoramy Gdańska Antoniego Möllera, Zeszyty Naukowe Politechniki Gdańskiej. Architektura, vol. 10: 1970, pp. 147-156; H. Lingenberg, op.cit., pp. 85-96; see the literature: Aurea Porta, cat. nr V.2., pp. 140-141. Do noty katalogowej została załączona literatura przedmiotu.

${ }^{20}$ Ulla Ehrensvärd, Handgezeichnete Veduten und Pläne in öffentlichen Sammlungen zu Stockholm und Uppsala betreffend Pommern, Mecklenburg, Brandenburg und Westpreußen, [in:] Lüneburger Beiträge, p. 34, no. 13; available online http://www.eurofresh.se/ulla/gdansk.html [Accessed 1.06.2018]. Comp. Cartographica Poloniae 1570-1930. Catalogue of manuscript sources in Swedish collections to the history of Polish territories. Katalog źródet rękopiśmiennych do historii ziem polskich w zbiorach szwedzkich, ed. Ulla EHRENsvärD, Warszawa 2008.

${ }^{21}$ Teresa ZaręBSKa, Przebudowa Gdańska w jego złotym wieku, Warszawa 1999.

${ }^{22}$ Grzegorz Bukal establishes the date of its creation for the years 1593-1599 and it may be close to the truth, see Grzegorz Bukal, Fortyfikacje Gdańska i ujścia Wisty 1454-1793, Sopot 2012, p. 13; the authorship of Möller is cautiously proposed by J. PA£UBICKI, op.cit., p. 541.

${ }^{23}$ G. BuKaL, op.cit., pp. 94-107. 
not published. A dozen or so years later, in 1617 a new cityscape of Gdańsk was made, almost as monumental as the earlier work (works) of Möller. It was a work of a Gdańsk illustrator and engraver Aegidius Dickmann (1595 - after 1648$)^{24}$. The panorama was made on seven copperplates of the total size $258 \times 54 \mathrm{~cm}^{25}$. Along with a series of 14 city views, the album Praecipuorum locorum et aedificiorum, quae in urbe Dantiscana visuntur adumbratio ${ }^{26}$ significantly updated the previous portraits of Gdańsk, including the changes in the city buildings.

Clearly in the first decades of the $17^{\text {th }}$ century the characteristic and commonly recognizable veduta of the city imprinted itself in the consciousness of the Gdańsk burghers. This is confirmed by the fact that the cityscape appeared not only in official paintings destined for public interiors, such as the famous Apoteoza Gdańska ('The Apotheosis of Gdańsk', 1608) by Isaac van den Block from the Red Room of the Main Town Hall ${ }^{27}$, or the earlier Grosz czynszowy ('Tribute Money', 1601) by Anton Möller. The panorama of Gdańsk also became frequently a background for admonitions for ill customs of the city inhabitants in the works created by the circle or imitators of Möller the Elder ${ }^{28}$ or equally eminent artist Hermann Han ${ }^{29}$. Ultimately the miniaturized form of the city view appeared on commemorative medals. The last of the mentioned

${ }^{24}$ See the entry of Anna Gosieniecka, Dickmann Idzi (Aegidius), [in:] Stownik Biograficzny Pomorza Nadwiślańskiego, vol. 1, ed. Stanisław GIERszewski, Gdańsk 1992, pp. 329-330; Paweł Groth, Nieznany sztych Idziego Dickmanna z panorama Gdańska, Zapiski Historyczne, vol. 24: 1958/1959, no. 2-3, pp. 193-196.

${ }^{25}$ In the collections of the Royal Library in Stockholm, Lit.: Aurea Porta, pp. 140-141, cat. nr V.3.

${ }^{26}$ Repr. and lit.: Aurea Porta, cat. V.2, p. 140-142. More detailed explanation of the layout: Z. JAKRZEWSKA-ŚNIEŻKo, Gdańsk w dawnych rycinach, pp. 16-17.

${ }^{27}$ Sergiusz Michalski, Gdańsk als auserwählte Christengemeinschaft, [in:] Ars Auro Prior. Studia Ioanni Białostocki Sexagenario Dicata, ed. William S. Heckscher, George Kubler, Warszawa 1981, pp. 506-515; Eugeniusz Iwanoyко, Apoteoza Gdańska. Program ideowy malowidet stropu Wielkiej Sali Rady Ratusza Głównego Miasta, Gdańsk 1976.

${ }^{28}$ Jan Harasimowicz, Antoni Möller - malarz, moralista, obywatel, Biuletyn Historii Sztuki, vol. 56: 1994, no. 3, pp. 339-358; idem, Doctrina Doctrinarum. Katechetyczne i społecznoobyczajowe treści „Dziesięciu Przykazañ” z Pruszcza Gdańskiego, Porta Aurea. Rocznik Zakładu Historii Sztuki Uniwersytetu Gdańskiego, vol. 2: 1993, pp. 55-99; idem, Danziger Maler Anton Möller als Bürger seiner Stadt und eifriger Moralist im Geiste der lutherischen Reformorthodoxie, [in:] Art, religion et société dans l'espace germanique au XVI' siècle, ed. Frank MuLLER, Strasbourg 1997, pp. 77-104.

${ }^{29}$ Jacek TyLicki, Obraz „Alegoria cnoty małżeńskiej”. Klucz do drugiego oblicza sztuki Hermanna Hana, Biuletyn Historii Sztuki, vol. 59: 1997, no. 1-2, pp. 38-59. The subject of controversy is both the authorship and the identification along with the symbolism of the people presented in the image (a prostitute and a Jew recognized by Tylicki), see: Edmund KizıK, O ubiorach żydowskich i gdańskich na przełomie XVI i XVII wieku. Uwagi w zwiazku z artykułem Jacka Tylickiego, Biuletyn Historii Sztuki, vol. 45: 2003, no. 1, pp. 135-143. 
artists was involved in the work on the first of Gdańsk medals with a realistic representation of the city. The object in question was a 30-ducat donatywa a coin-medal commemorating King Sigismund III Vasa, with the diameter $50.5 \mathrm{~mm}$, dated 1617 and minted again in 1619 and $1620^{30}$. The appearance of city views on gift medals was an entirely new stage in the development of European medallic art, in which Gdańsk undoubtedly played a significant role in the $17^{\text {th }}$ century Previous incarnations of the concept from the turn of the $17^{\text {th }}$ century displayed the motifs of besieged or captured towns ${ }^{31}$. The concept of the creators of the Gdańsk medal was different: besides making the city famous, its imagery was to accentuate the city's equality in the political relation with the King of Poland. Displaying the might of the newly erected fortifications was intended as a somewhat preventative measure.

In the literature, the beginnings of modern medal-making are associated with the portrait medal of John VIII Palaeologus created by Pisanella (Antonio Pisano), and the concept adopted by the circle of Emperor Maximilian I soon became a propaganda tool of Renaissance rulers. The custom of giving and wearing medals became quite widespread among the Prince-Electors of the Holy Roman Empire, and in the 1530s it reached Poland, ruled then by the Jagiellonian dynasty ${ }^{32}$. The growth of the popularity of medallic art at the turn of the $16^{\text {th }}$ century initially was an elite reception of ancient models; only during the Baroque period this small-scale goldsmith art gained immense popularity $^{33}$. It was considered as an elegant gift, but it was predominantly a tool of political propaganda. Medals were given by rulers as a sign of friendship and favour, which is directly referred by German terms for this type of medal Gnadenpfennig, Gnadenmedaille. Medals on chains became a part of recipients' fine outfits. Soon they also began to be treated as objects to collect. A specific type of gift medals in the $16^{\text {th }}$ century became Patenpfennig ${ }^{34}$ which commemorated baptism; later this name also covered other commemorative gifts connected with this sacrament.

${ }^{30}$ Published many times i.e. in: Maria STAhr, Medale polskie i z Polska zwiazane od XVI do XVIII wieku. Katalog zbiorów Muzeum Narodowego w Poznaniu, Poznań 2008, no. 31, p. 47; Gdańsk dla Rzeczypospolitej w służbie Króla i Kościoła, ed. Jolanta TAlBIERsKA, Gdańsk 2004, kat. nr I. 54, p. 156; Jacek TYLICKI, O historii sztuki i numizmatyce, czyli kto projektował niektóre donatywy Zygmunta III, Biuletyn Numizmatyczny, 2009, no. 1, pp. 4-5; Mari STAHr, Medale Wazów w Polsce 1587-1668, Wrocław 1990, p. 79 and fn. 90.

${ }^{31}$ M. Stahr, Medale Wazów, pp. 66-74.

${ }^{32}$ Monuments known from later casts were usually ordered from creators operating outside of Poland, see: M. STAHr, Medale polskie i z Polska związane, cat. no. 1-8, pp. 20-27; eadem, Medale Wazów, pp. 20-23.

${ }^{33}$ Adam WięCEK, Sebastian Dadler. Medalier gdański XVII wieku, Gdańsk 1962, p. 7.

${ }^{34}$ Edmund KızıK, Wesele, kilka chrztów i pogrzebów. Uroczystości rodzinne w mieście hanzeatyckim od XVI do XVIII wieku, Gdańsk 2001, pp. 160-166. 
The first medals for the rulers of Poland and for eminent representatives of the greatest Polish and Lithuanian families appeared during the rule of Sigismund I; they belong to the so-called ruler's medals. They were created by artists working abroad. In the late $16^{\text {th }}$ century there appeared medals intended to commemorate certain historic events, which included also the medals struck during the rule of Stephen Báthory to celebrate the successes during the Livonian campaign ${ }^{35}$. Eventually, along with migrating artists the concept of striking commemorative medals reached Gdańsk. This was to an extent a natural process, as this affluent city not only had the right to mint its own coin but also employed the greatest medallists of that era (Philip Klüwer, Daniel Klüwer, Samuel Ammon, Sebastian Dadler). Yet, while the medals of favour or ruler's medals were given to the subjects, the Gdańsk medals were assigned a different function. They were to honour Polish kings by commemorating their weddings, births of children and visits to the city while simultaneously demonstrating the wealth, military power and generosity of the giver. Yet actually, this above all concerned the payment of the tribute owed by Gdańsk to the king of Poland, amounting to 2,000 Hungarian florins "in gold of good weight". In return for generous charters, the privilege from 16 June 1454 obliged the city to pay a proper compensation: "Durch welcher gobung willen und bekentnisz unser hirszoft die vorgnanten unsere burgere der egnanten Rechten statt Danczke keginwortige und zcukunftige als unsere undertainige alle ior ierlichen und in ewigen geczeiten czwetawsint ungerische gulden puris guldis und rechtfertiger woge [...] uns und unsern nochkomlingen, konigin zcu Polan, beczalen sullen $[\ldots]]^{36}$. This tax, sometimes described also as the (Gdańsk) tribute ${ }^{37}$, from the mid- $16^{\text {th }}$ century was registered in the city treasury office (kamlaria) as the so-called King's instalments ("Königliche Ratengelder") ${ }^{38}$. It was paid yearly in two instalments: on St. John's Day (21 June) and on Christmas Day (25 December). The privilege of 22 July 1525 mentions additional 3,000 Mark (20 grosze each) or 2,000 florins (30 grosze each), paid in instalments on the Feast of the Annunciation (25 March) and on Michaelmas (29 September) ${ }^{39}$. In 1766, in

${ }^{35}$ M. Stahr, Medale polskie i z Polska związane, cat. nr 26-27, pp. 41-42; eadem, Medale Wazów, p. 23.

${ }^{36}$ See the privilege printed many times: Paul Simson, Geschichte der Stadt Danzig, vol. 4, Danzig 1918, no. 137, pp. 107-108; Max Foltz, Geschichte des Danziger Stadthaushalts, Danzig 1912, p. 131.

${ }^{37}$ See Beata Możejкo, Czynsz gdański w polityce Kazimierza Jagiellończyka i jego synów, Gdańsk 2004, p. 5, fn. 1. We may complement the statement of the author saying that the term 'instalment' is not the idea of historians, but it resulted from the early modern source material.

${ }^{38}$ Paul Simson, Geschichte der Stadt Danzig, vol. 1, Danzig 1913, p. 276.

${ }^{39}$ M. FolTz, op.cit., pp. 132-133. 
the face of the decreasing value of the due payments (excluding 2,000 ducats) the total amount was increased to 2,666 florins and $20 \mathrm{grosch}^{40}$. Another duty was the obligation to host the king and the accompanying court for three days, with the costs paid by the royal city (so-called "Station", "Stationsgeld") ${ }^{41}$. In the second half of the $16^{\text {th }}$ century a flat rate of 750 Mark (500 guldens) was established, to be paid on the Feast of St. Martin (11 November), which was later changed to Christmas Day ${ }^{42}$. The payments of Elbląg to Polish kings were significantly lower, set in the privileges at 400 ducats paid on Whitsunday ${ }^{43}$. By analogy to Gdańsk, these were called the "Elbląg instalments".

Since the rule of Casimir Jagiellonian, the amount of the Gdańsk royal instalments did not fluctuate and e.g. in the time of Sigismund August it was the equivalent of $7.06 \mathrm{~kg}$ ( 1 ducat $=3.53 \mathrm{~g}$ of gold). For the purpose of the ceremonial of public delivery of the money ${ }^{44}$, and in order to preserve the accounting function, the tax or its part was sometimes delivered in the form of coins minted especially for the occasion, worth several or more standard ducats. Relatively large coins-medals provided enough surface to represent sufficiently clear images with an accompanying commemorative inscription. As to the weight, the initial model was the Danish-Portuguese style coin (Portugaleser, Portuguez), a large gold coin worth 10 ducats; there were also such coins of double, or even triple weight. At the end of the $16^{\text {th }}$ century a portugaleser weighed $33.92 \mathrm{~g}$. While during the reign of Sigismund III Vasa the weight of the gift coins equalled that of 20 or more ducats, during the reign of both younger kings from that dynasty it decreased to less than ten ducats.

Since the $19^{\text {th }}$ century Polish literature on the subject has been using the term donatywa to describe this particular type of a payment medal ${ }^{45}$. The

${ }^{40}$ Ibid., p. 133.

41 “[...] dass die Bürger zu Danzig als des Königs Unterthänige alle Jahr, jährlich und zu ewigen Zeiten den Königen zu Polen drey Tage Station, der Königlichen Majestät gebührend, und allem Hofgesinde gnüglich geben sollen"; Gottfried LeNGNICH, Ius publicum civitatis gedanensis oder der Stadt Danzig Verfassung und Rechte, ed. Otto GüNTher, Danzig 1900, p. 92 (Cap. VIII: Von des Königes Hofhaltung, wenn er sich in Danzig befindet, und von seinen Einkünften).

${ }^{42}$ In 1766 the annual donation was raised to 666 florins 20 grosch (1,000 Mark).

${ }^{43}$ Witold Szczuczko, Postanowienia wielkiego przywileju królewskiego z 1457 r., [in:] Historia Elblaga, vol. 2/1, ed. Andrzej Groth, Gdańsk 1996, pp. 12-14. The text of the privilege: Acten der Ständetage Preussens unter der Herrschaft des Deutschen Ordens, vol. 4, ed. Max ToEppen, Leipzig 1884, no. 384, pp. 597-599. See: Witold Szczuczko, Przywileje królów polskich dla Elblaga, Gdańsk 1991.

${ }^{44}$ Money was handed in to the monarch or his envoys in costly goblets and bowls.

${ }^{45}$ Bogumiła Haczewska, Donatywy pomorskie, [in:] Sztuka XVII wieku w Polsce. Materiały Sesji Stowarzyszenia Historyków Sztuki, Kraków, grudzień 1993, Warszawa 1994, pp. 275-288. 
etymology of that term was explained already in Encyklopedia Orgelbranda ${ }^{46}$; however, it is still pointed out that the function of such an object has been differently understood ${ }^{47}$. The oldest gift coin, or donatywa, is considered to be an alleged historical coin struck in silver, perhaps in 1552 during Sigismund August's two-month stay in Gdańsk; the inscription on the reverse side reads: Monumentum + regale + civita[tis] Gedanensis ${ }^{48}$. Yet, it appears that the first actual donatywa was the seven-ducat coin with the bust of Stephen Báthory of $1582^{49}$, with a characteristic inscription on the outer ring: Ex auro solido civitas Gedanensis fieri fecit, which refers to the content of the 1454 privilege: "[... czwetawsint ungerische gulden] puris guldis und rechtfertiger woge" 50 . The next coin with the tax due to King Stephen Báthory comes from $1585^{51}$; the next, undated, probably from 1586(? $)^{52}$.

As has been mentioned above, the first Gdańsk thirty-ducat medal struck in gold, as well as in silver, was created in 1617 and dedicated to King Sigismund III Vasa (the obverse contains a portrait of the king in parade armour with an appropriate inscription). The reverse shows a panorama of Gdańsk, which was an imitation of engraved and painted vedute. The city and the river estuary are seen from Biskupia Górka against the sea; at the foot of the fortification the silhouettes of pedestrians and carts enliven the image, which clearly resembles the decorations of the veduta by Anton Möller the Elder. The characteristic towers of Gdańsk temples rise above the city: the massive one of St. Mary's, the slender one of St. John's and the pointed tower of the Main Town Hall. Individual bastions surrounding the town on the south-eastern side are emphasized. The grid of streets running towards the canal of the invisible Motława [Motlau] has been treated very schematically, representing the concept of densely built houses implying a populous city. On the horizon is the sea with sailing ships approaching the port. Some topographic details were even distinguished by tiny legends, such as the rivers: Raduna F[luvius] and Vistula F[luvius], which resembles the explanations on Möller's and Dickman's

${ }^{46}$ Kazimierz Bujnicki, Donatywa, [in:] S. Orgelbranda Encyklopedja Powszechna, vol. 7, Warszawa 1900, pp. 277-278; Zygmunt GLOGER, Encyklopedia staropolska ilustrowana, vol. 2, p. 36.

${ }^{47}$ All the opinions expressed in the discussion were compiled by J. TyLICKI, O historii sztuki i numizmatyce, pp. 4-5, fn.

${ }^{48}$ The monument known only from subsequent moulds see: Aurea Porta, cat. nr VIII, 124; VIII, 125.

${ }^{49}$ Aurea Porta, cat. nr VII, 130.

${ }^{50}$ The privilege was many times published see: P. Simson, Geschichte der Stadt Danzig, Bd. 4, nr 137, pp. 107-108; M. Foltz, Geschichte des Danziger Stadthaushalts, p. 131.

${ }^{51}$ Polish: „Donatywa pięciodukatowa”; Aurea Porta, cat. nr VIII, 138.

${ }^{52}$ Gdańsk dla Rzeczypospolitej, cat. no. I. 50. 
cityscapes. To prevent misunderstandings, the city coat of arms is presented over the panorama, held up by two putti.

The medal was created by the engraver Samuel Ammon (ca. 1590-1620), one of the greatest authors of this type of small goldsmith items not only in Poland but also in whole central and northern Europe. Ammon, whose monogram can be found on the medal, did his work on the basis of the project by a Gdańsk painter Hermann $\mathrm{Han}^{53}$. Han's co-authorship is confirmed by the entry in the kamlaria records, which mentions the payment for the drawings intended for the Portuguese-style coins ${ }^{54}$. The note on Han's contract was found by Janusz Pałubicki, and it was described and discussed by Jacek Tylicki; seemingly the latter wrongly interpreted the abbreviation AVHK put on the medal ${ }^{55}$. Tylicki, influenced by the mentioned entry in kamlaria records, read the last letter of the sigla as the small " $\mathrm{h}$ " (instead of capital "K"), and thus he proposed to read it as "A[bgerissen] V[on] H[ermann] h[an]", which means "designed by Hermann Han". Without changing the reading, the initials may simply refer to the name and function of the mayor, kamlaria's superordinate, $\mathrm{A}$ [rnold] $\mathrm{V}$ [on] H[olten] K[ammerer]. Von Holten's signature can be found under the payment for H.Han, the possibility that the concept of the medal was created by the narrow group of people ruling the city cannot be excluded. The message of the medal is quite clear. The city is at its peak export capability (the highest trade turnover was recorded in 1618$)^{56}$ and directly evokes its features connected with trade and sea. The donatywa given to the Polish king also displays the fortifications that protect the city, which is a clear hint that the people of Gdańsk are able to protect their interests on their own, defending them against both external and internal threats. The notes in the Memoir of Albrycht Radziwiłł ${ }^{57}$ confirm that at the time of King Władysław IV the memory of the failed siege of the city by the army of Stephen Báthory in 1577 was still freshThe panorama of Gdańsk was represented on city medals multiple times. The literature reveals that there are at least 32 medals of this kind, and as many as 27 of them were struck in the $17^{\text {th }}$ century while only 5 are the $18^{\text {th }}$-century

${ }^{53}$ J. Tylicki, O historii sztuki i numizmatyce, pp. 4-5; idem, Donatywa medalowa z perspektywicznym widokiem Gdańska, [in:] Herman Han. Mistrz światła i nokturnu. Narodziny baroku w malarstwie dawnej Rzeczpospolitej, ed. Marcin Osowski, Pelplin 2008, pp. 56-73.

${ }^{54}$ Janusz PaŁubicki, Malarze gdańscy. Malarze, szklarze, rysownicy i rytownicy w okresie nowożytnym w gdańskich materiałach archiwalnych, vol. 1, Gdańsk 2009, p. 284.

${ }_{55}^{5} \mathrm{~J}$. TYLICKI, O historii sztuki i numizmatyce, pp. 4-5.

${ }^{56}$ Maria BogucKa, Handel zagraniczny Gdańska w pierwszej połowie XVII wieku, Wrocław 1970, p. 15; Czesław BIERNAT, Apogeum handlu gdańskiego w pierwszej połowie XVII wieku. (Na marginesie pracy Marii Boguckiej, Handel zagraniczny Gdańska w pierwszej połowie XVII wieku, Wrocław-Warszawa-Kraków 1970), Zapiski Historyczne, vol. 36: 1971, no. 4, pp. 145-159.

${ }^{57}$ Albrycht Stanisław RadziwiŁe, Pamiętnik o dziejach we Polsce, vol. 2: 1637-1646, trans. and ed. Adam Przyboś, Roman Żelowski, Warszawa 1980, p. 65 (30 October 1637). 
versions $^{58}$. It should be stressed that part of the medals are known in several variations, differing in details. Most often they were the mentioned donatywy, sometimes also other commemorative medals, for example the medals with Gdańsk cityscapes minted to celebrate the conclusion of the Treaty of Oliwa in 1660. At least six such medals are known, struck both in gold and in silver ${ }^{59}$. The last medals with views of Gdańsk come from 1754 (funded to celebrate the tricentennial anniversary of the incorporation of Prussia to the Crown) ${ }^{60}$ and from 1760, struck to commemorate the centenary of the Treaty of Oliwa. They draw upon representations known from earlier versions.

Gold and silver Gdańsk medals presenting the city perfectly complemented the image created by poets and various poetasters and supported in numerous encomiums written to praise the city, its coat of arms and the City Council - laus urbis or in honorem Magistratus Gedanensis ${ }^{61}$. The City Council generously funded and - especially in the $18^{\text {th }}$ century - amply awarded all kinds of authors of literature praising the City. The accounts marked "Verehrungen" reveal expenses for various more or less honest flatterers ${ }^{62}$. Besides the king and its closest entourage, the medals were given to the members of the city authorities and to the honoured guests of the City Council ${ }^{63}$. In the $18^{\text {th }}$ century the weakening city became much more careful about this kind of now-and-then expenses; also long breaks in the operation of the city mint resulted in slowing the activity of medallists.

${ }^{58}$ See: M. STAHr, Medale Wazów, catalogue no. 23 (1617 or 1619, 1620), 44 (1635), 52 (1642), 64 (1653), 69 (115), 71 (1660), 72 (1660), 75 (121), 76 (1660) and Siegfried RüHLE, Die historischen Medaillen der Stadt Danzig. Ein Beitrag zur Geschichte der Danziger Medaillenkunst und ihrer Künstler, Zeitschrift des Westpreussischen Geschichtsvereins, Bd. 68: 1928, pp. 243-308, no. 10 (1617?, 1619), 11 (1635), 14-17 (1642), 18 (1644), 21 (1646), 22 (1650), 23 (1653), 24-25 (1654), 30-35 (1660), 38-39 (1660), 43 (1683), 44 (1685), 46-47 (1696), 49 (1693), 50 (before 1696), 52 (1697), 66 (1733), 70-71 (1734), 72 (1754), 74 (1760). The medal with the panorama of Gdańsk of 1734 minted in Nuremberg is different from remaining medals as it was created to commemorate the fact of the city's submission to August III after the siege by the Russian-Saxonian armies. See Gdańsk dla Rzeczypospolitej, cat. no. IV.18.

${ }^{59}$ M. STAHr, Medale Wazów, cat. no. 71-76.

${ }^{60}$ Edmund Kızıк, Gdański medal jubileuszowy z okazji trzechsetlecia inkorporacji Prus do Polski w 1754 roku, Zapiski Historyczne, vol. 77: 2012, no. 2, pp. 79-91.

${ }^{61}$ E. KotARsKi, op.cit., pp. 189-202, 287-302.

${ }^{62}$ Edmund Kızıк, Wynagrodzenia za dzieła dedykowane lub ofiarowane Radzie Miejskiej Gdańska w XVII w. Źródłowy przyczynek do dziejów mecenatu miejskiego, Rocznik Biblioteki Narodowej, vol. 43: 2012, pp. 75-85; idem, Remuneration for Works Dedicated or Donated to the City Council of Gdansk in the $17^{\text {th }}$ century. Source-based contribution to the history of urban arts sponsorship, Polish Libraries, vol. 2: 2014, pp. 167-179.

${ }^{63}$ See the group of those who were honoured with the medal minted in 1754 upon the $300^{\text {th }}$ anniversary of the incorporation of Gdańsk and Prussia into Poland, E. Kızıк, Gdański medal jubileuszowy, pp. 84-86. 
Other large cities of Prussia only occasionally reached for this kind of propaganda tool. For example in Torun it was announced that, to celebrate the breaking of the Swedish siege in 1629, the day of 16 February would be celebrated as a thanksgiving day starting from the year $1630^{64}$. To commemorate this, medals presenting the Torun panorama in flames were struck in silver and gold $^{65}$. It is the first known total view of this city. Along with the subsequent panorama of Torun recorded on the 1659 medal, minted to commemorate the end of the Swedish occupation of the city, the medals belong to the ballistic sub-type of this goldsmith $\operatorname{art}^{66}$.

Let us return to Gdańsk. After the death of Ammon, the next medal with a cityscape appeared only 15 years later. However, the work, created in 1635 to celebrate the armistice with the Swedes in Sztumska Wieś, was not created by a Gdańsk artist, but by Hand Rieger from Wrocław ${ }^{67}$. Among foreign artists, the practice of making and sending to the City Council of Gdańsk works praising the city and its authorities in hope of an appropriate remuneration was quite common. The city usually reciprocated with a suitable fee. However, this time the artist was disappointed. Although the inscription clearly answered the wishes of the Gdańsk people (Gedanum sive Dantiscum emporium opulentissimum, amplissimum et venustiss), Rieger's work was objected to by the Gdańsk City Council. The reason could have been the vedute itself, which extremely faithfully follows Ammon's representation of 1617. Most likely, however, the City Council acted in the name of local artists as already in the same or the following year (the medal is not dated) there came the version of Sebastian Dadler and Johann Höhn, which presented the personifications of Mercy and Truth shaking hands in agreement against the panorama of Gdańsk ${ }^{68}$. The creators used the Gdańsk cityscape known from the published version by Piscator.

${ }^{64}$ Jacob Heinrich Zernecke, Thornische Chronica in welcher die Geschichte dieser Stadt von 1231 bis $1726 \ldots$ zusammen getragen worden, Berlin 1727, pp. 280; idem, Das bey denen schwedischen Kriegen bekriegte Thorn oder zuverläszige Erzehlung desjenigen was sich bey dieser Stadt im Jahr 1629, 1655, 1658 und 1703... denckwürdiges zugetragen..., Thorn 1711, pp. 17-18.

${ }^{65}$ J. H. ZerneCKe, Das bey denen schwedischen Kriegen bekriegte Thorn, p. 18; see Mennice i monety toruńskie 1233/1238-1765. Katalog wystawy, ed. Adam MusiaŁowski, Toruń 2006, p. 17, no. 78-80 (silver), 81 (gold); Adam MusiaŁowski, Panorama miasta na monetach i medalach toruńskich, [in:] Pozaekonomiczne funkcje monet. X Ogólnopolska Sesja Numizmatyczna $w$ Nowej Soli, Poznań 1995, pp. 103-120; M. STAHR, Medale Wazów, cat. no. 50-51.

${ }^{66}$ M. STAHR, Medale polskie i $z$ Polska zwiazane, cat. no. 60, pp. 70-71.

${ }^{67}$ Eadem, Medale Wazów, cat. no. 41.

${ }^{68}$ A. WiĘCEK, op.cit., cat. 113; M. STAHr, Medale Wazów, cat. no. 65; eadem, Medale polskie i $z$ Polska zwiazane, cat. no. 42. 
An entirely new veduta was shown on a large ( $80 \mathrm{~mm}$ diameter) medal by Sebastian Dadler of $1642^{69}$, celebrating King Władysław IV. The reverse is filled by a large panorama of Gdańsk with the bay in the background, including also the port roadstead with the Wisłoujście Fortress and Zuławy. The viewpoint is Grodzisk, and the prominent element is the system of Gdańsk fortifications, significantly strengthened during the conflict with Sweden. The medal constitutes a homage paid to Władysław IV, commemorating his earlier military successes during the war with Russia. The obverse presents an equestrian portrait of the ruler on the background of the Smoleńsk battlefield.

This very successfully executed, detailed panorama by Dadler, which also included walking people, horse-drawn carts and punt boats on the Vistula, was later frequently reused and imitated, for example in the donatywy of $1644-1647^{70}$. However, later creators made significant simplifications (e.g. Johann Höhn's medal of 1653) $)^{71}$. A rare and entirely unique view among those presented so far was recorded on the medal commemorating the wedding of Władysław IV and Marie Louise Gonzaga in $1646^{72}$. Sebastian Dadler put on the reverse a seascape, with a prominent sail ship entering the port canal at the fortifications of the Wisłoujście fortress. The details of the Wisłoujście bulwarks are presented non-schematically and could be even used to reconstruct the original fortifications. The city itself is presented on the medal in an unbreakable union with Poland (the inscription on the band reads: nihil ista secabit), since, according to the interpretation of Maria Stahr, the coats of arms of Poland and Gdańsk are presented as equal to each other, held on a sash by a hand emerging from a cloud. This is also in agreement with how the people of Gdańsk perceived the position of their town in the Polish-Lithuanian Commonwealth ${ }^{73}$. However, if the medal was to present the arrival of the future queen to Gdańsk, it turned out to be premature because - as we know - due to the king being laid down with gout. As a result, the wedding in Gdańsk was ultimately cancelled, and Marie Louise came to the city not by sea, as it had been planned, but by land.

The message conveyed by Johann Höhn's medal struck in 1654 to commemorate the bicentennial anniversary of the incorporation of Gdańsk and

${ }^{69}$ A. WięCEK, op.cit., cat. no. 113, pp. 66; M. STAHR, Medale Wazów, cat. no. 52, pp. 121-124.

${ }^{70}$ M. STAнr, Medale Wazów, pp. 121-123, cat. no. 52.

${ }^{71}$ Ibid., pp. 123, 165.

72 A. WięCeK, op.cit., cat. no. 120, p. 68; M. STAHR, Medale Wazów, pp. 146-147, cat. no. 55.

${ }^{73}$ Edmund Kızıк, Inkorporacja Prus do Polski i wojna trzynastoletnia w świetle historiografii pruskiej (2 połowa XVI-XVIII w.). U źródeł świadomości historycznej w Prusach Królewskich, [in:] My i oni. Spoleczeństwo nowożytnej Rzeczypospolitej wobec państwa, ed. Wojciech KRIEGSEISEN, Warszawa 2016, pp. 75-97. 
Prussia to Poland in 1454 is interesting from the ideological point of view ${ }^{74}$. In the foreground there is a prominent eagle of Royal Prussia, which with a raised sword overthrows the rule of the Teutonic Order (at the bottom on the ground lies the Teutonic Order's coat of arms). The background is the widespread map of Royal Prussia along with Żuławy and the panorama of Gdańsk (a simplified fragment of Dadler's medals); even villages appear on the medal. Above the contours of the map hovers the White Eagle. This motif was slightly changed on the medal for the subsequent lay anniversary celebration of 1454 . On the medal designed by Johann Donnet, two eagles - of the Crown and of Royal Prussia - torment a fallen cross of the Teutonic Order. The map of Royal Prussia was replaced here by the panorama of Gdańsk known from Dadler's design of 1646. The last medal presenting Gdańsk's panorama was created in 1760, to commemorate the centenary of the Treaty of Oliwa ${ }^{75}$. The authors of the medal again referred to Dadler's view of Gdańsk, yet this time only a fragment of the city was shown, focusing on the axis leading from the Wyżynna Gate, with the whole Torturer's Tower complex and the characteristic towers of the churches and the town hall rising above the city. The background shows the Vistula estuary and numerous sail ships anchored both at the roadstead and in the canal leading to the port. The reverse shows the silhouette of the Oliwa monastery and the abbots' palace, seen from the south-east, from the direction of Gdańsk.

The incorporation of Gdańsk to Prussia in 1793 and a foreign garrison taking over the control of the fortifications ended the period of the modern autonomy of this republican city. A new, different political model of Prussian monarchy resulted in a complete abandonment of historical and cognitive paradigms that had been cultivated for centuries. The new situation left no space for propagating the idea of independent Gdańsk in local medallist art.

trans. by Agnieszka Chabros

Received 5 October 2018

Received in revised form 29 November 2018

Accepted 7 December 2018

Prof. dr hab. Edmund Kizik

Institute of History

Polish Academy of Sciences

e-mail:edmund.kizik@ug.edu.pl

ORCID ID: 0000-0002-5877-2025

\footnotetext{
${ }^{74}$ See the discussion: M. STAhr, Medale Wazów, pp. 164-169; E. Kızıк, Gdański medal jubileuszowy.

${ }^{75}$ Gdańsk dla Rzeczypospolitej, cat. no. IV, 19.
} 
In Gold and Silver: Panoramas of GdańsK ON Coins AND Medals IN THE $17^{\mathrm{TH}}$ AND $18^{\mathrm{TH}}$ CENTURY

\section{Summary}

Key words: Gdańsk, medallist, political iconography, symbolism of the city panorama, $17^{\text {th }}-18^{\text {th }}$ centuries

Despite the lush development of painting in late medieval Gdańsk (the second half of the $15^{\text {th }}$ - the first half of the $16^{\text {th }}$ ) no realistic depictions of the city or its part have survived. The first realistic panoramic view of Gdańsk was made relatively late, just before 1573. It was published in Cologne in 1575 and again in the following year in the atlas by Georg Braun and Frans Hogenberg, Civitates orbis terrarum. The novelty of Braun and Hogenberg found many followers in Gdańsk, who from the 1590s until the third decade of the $17^{\text {th }} \mathrm{c}$. created their own original panoramic views, characterized by a much greater accuracy and faithfulness to the details of their city. The veduta of Gdańsk (221 x $35.3 \mathrm{~cm}$ ) made in 1592/1593 by Anton Möller the Elder, was followed in 1599 by a painting version, nowadays lost, which was a gift for Venice. In 1617 Aegidius Dickmann created a panoramic view of Gdańsk with an album of 14 views of streets and districts.

This image in a miniaturized form finally found its way to commemorative medals, an innovation in this part of Europe. It appeared for the first time in a 30-ducat donatywa, or a coin-medal commemorating King Sigismund III Vasa, made by Samuel Amman and Herman Han in 1617. This panorama shows a harbour city belted with powerful fortifications, with its characteristic churches, and ships on the horizon; the king is portrayed on the reverse. Apart from making the city famous, the coins with Gdańsk vedutas emphasized that in the political alliance with the King of Poland, this mighty city is equal. It is in these coins that Gdańsk paid an annual tax amounting to 2,000 Hungarian florins due to the Polish kings.

The panoramic view of Gdańsk was repeatedly recorded on occasional medals and gift coins. There are at least 32 medals of this type, out of which as many as 27 were minted in the $17^{\text {th }} \mathrm{c}$.; the remaining 5 come from $18^{\text {th }} \mathrm{c}$. Most commonly, these were golden donatywas, sometimes commemorative historical medals minted in gold and silver, e.g. to commemorate the peace concluded in Oliwa in 1660. The last medals with the views of Gdańsk date back to 1754 and were minted to commemorate the $300^{\text {th }}$ anniversary of incorporation of Prussia to the Crown, and to 1760 which was the date of the $100^{\text {th }}$ anniversary of the peace of Oliwa. Other great cities of Royal Prussia only sporadically ordered such works. The gold and silver medals of Gdańsk with the city's panorama were complemented by the panegyric image of a proud, mighty city invoked by writers - "laus urbis" or "in honorem Magistratus Gedanensis". In the $17^{\text {th }} \mathrm{c}$. the City Council generously rewarded such writers. In the $18^{\text {th }} \mathrm{c}$. a weakening city seemed to be spending less money on propaganda purposes. After the occupation of Gdańsk by Prussia in 1793 these kinds of medals were not minted anymore. 
In Gold und Silber. Panoramen von Danzig

AUF BILDERn Und MedaILlen IM 17. UND 18. JahrhunderT

\section{Zusammenfassung}

Schlüsselwörter: Danzig, Medaillenherstellung, politische Ikonografie, Symbolik von Stadtpanoramen, 17. bis 18. Jahrhundert

Trotz der lebhaften Entwicklung der Malerei im spätmittelalterlichen Danzig (2. Hälfte des 15. bis Mitte des 16. Jahrhunderts) haben sich aus dieser Zeit keine realistischen Darstellungen der Stadt oder von Teilen von ihr erhalten. Das erste realistische Panoramabild von Danzig entstand relativ spät, erst vor dem Jahr 1573. Es wurde 1575 in Köln publiziert und im nächsten Jahr erneut im Atlas von Georg Braun und Frans Hogenberg Civitates orbis terrarum. Die Innovation der Arbeit von Braun/ Hogenberg fand in Danzig viele Nachahmer. Sie schufen originelle Panoramen, die von den 90er Jahren des 16. Jahrhunderts bis ins dritte Jahrzehnt des 17. Jahrhunderts entstanden und die sich durch eine weitaus größere Genauigkeit und Treue bei der Wiedergabe der Details im Anblick der Heimatstadt auszeichneten. Aus den Jahren 1591/92 stammt eine Vedute von Danzig (221 x 35,2 cm) von Anton Möller dem Älteren, um 1599 entstand eine verlorene gemalte Version dieses Werks, die ein Geschenk für Venedig war. 1617 entstand ein Werk von Aegidius Dickmann, ein Panorama von Danzig zusammen mit einem Album mit 14 Ansichten von Straßen und Stadtteilen.

Schließlich gelangte das Bild Danzigs in miniaturisierter Form auf Gelegenheitsmedaillen. In diesem Teil von Europa war das eine völlige Neuerung. Zum ersten Mal wurden sie im Werk von Samuel Amman und Herman Han von 1617 gezeigt, ein Donativ im Wert von 30 Dukaten, also eine goldene Geschenkmünze zu Ehren von Sigismund III. Wasa. Das Panorama zeigt eine ausgedehnte Hafenstadt, die von mächtigen Befestigungen umgeben ist, mit den typischen Silhouetten von Kirchen und mit Schiffen am Horizont. Auf der Rückseite findet sich ein Porträt des polnischen Herrschers. Neben dem Lobpreis der Stadt selbst betonten die Münzen mit den Veduten von Danzig die Macht der Stadt und ihre Gleichberechtigung in der politischen Verbindung mit dem polnischen König. In solchen Münzen entrichtete Danzig die jährliche Steuer für die polnischen Könige in Höhe von 2000 ungarischen Gulden (Dukaten).

Das Panorama von Danzig wurde vielfach auf Gelegenheitsmedaillen und Geschenkmünzen verewigt. Wir besitzen mindestens 32 Medaillen dieser Art, von denen gleich $27 \mathrm{im}$ 17. Jahrhundert geschlagen wurden, während 5 aus dem 18. Jahrhundert stammen. Am häufigsten waren das die erwähnten goldenen Donative, manchmal in Gold und Silber geschlagene historische Gelegenheitsmedaillen, z. B. zum Gedenken an den Abschluss des Friedens von Oliva 1660. Die letzten Medaillen mit Ansichten von Danzig stammen von 1754, zum Gedenken an den 300. Jahrestag der Inkorportion von Preußen in die Krone, sowie aus dem Jahr 1760 zum 100-jährigen Jubiläum des Friedens von Oliva. Die übrigen großen Städte des Königlichen Preußens bestellten nur sporadisch Werke dieser Art. Die goldenen und silbernen Medaillen aus Danzig mit dem Panorama ergänzten das von den Literaten geschaffene, panegyrische Bild einer stolzen, großen Stadt, das „laus urbis“ oder auch „in honorem Magistratus Ge- 
danensis“. Im 17. Jahrhundert wurden die Schöpfer der Literatur zum Lob der Stadt vom Stadtrat reichlich entlohnt. Im 18. Jahrhundert gab die schwächelnde Stadt Mittel für propgandistische Zwecke mit größerer Zurückhaltung aus. Nach der Übernahme von Danzig durch die Preußen 1793 wurden Medaillen dieser Art nicht mehr geprägt.

\author{
W ZŁocie I SREbrze. Panoramy Gdańska \\ NA MONETACH I MEDALACH W XVII-XVIII WIEKU
}

\title{
Streszczenie
}

Słowa kluczowe: Gdańsk, medalierstwo, ikonografia polityczna, symbolika panoramy miasta, XVII-XVIII wiek

Mimo bujnego rozwoju malarstwa w późnośredniowiecznym Gdańsku (druga połowa XV - połowa XVI w.) nie zachowały się z tego czasu żadne realistyczne wyobrażenia miasta lub jego części. Pierwszy realistyczny panoramiczny obraz Gdańska powstał stosunkowo późno, dopiero przed 1573 r. Został opublikowany w Kolonii w 1575 r. oraz powtórnie w roku następnym w atlasie Georga Brauna i Fransa Hogenberga Civitates orbis terrarum. Nowatorstwo pracy Brauna-Hogenberga znalazło wielu gdańskich naśladowców. Ich dziełem stały się oryginalne panoramy powstające od lat dziewięćdziesiątych XVI w. aż po trzecią dekadę XVII w., które charakteryzowały się dalece większą dokładnością i wiernością w oddawaniu detali wyglądu rodzimego miasta. Z lat 1592-1593 pochodzi weduta Gdańska (221 x 35,3 cm) Antona Möllera Starszego, około 1599 r. powstała zaginiona wersja malarska tego dzieła - dar dla Wenecji. W 1617 r. powstało dzieło Aegidiusa Dickmanna - panorama Gdańska wraz $\mathrm{z}$ albumem 14 widoków ulic i dzielnic.

Obraz Gdańska w zminiaturyzowanej postaci ostatecznie trafił na okolicznościowe medale. W tej części Europy było to całkowite nowatorstwo. Po raz pierwszy ukazano je w dziele Samuela Ammana i Hermana Hana z 1617 r. - trzydziestodukatowej donatywie, czyli złotej monecie podarunkowej dla uczczenia króla Zygmunta III Wazy. Panorama ukazuje rozległe, opasane potężnymi fortyfikacjami miasto portowe, z charakterystycznymi sylwetkami kościołów oraz statkami na horyzoncie. Na odwrocie sportretowano władcę Polski. Obok rozsławiania samego miasta monety z wedutami Gdańska podkreślały jego potęgę oraz równoprawność w związku politycznym z królem Polski. W takich monetach Gdańsk uiszczał coroczny podatek należny królom polskim w wysokości 2000 guldenów węgierskich (dukatów).

Panoramę Gdańska wielokrotnie utrwalano na okazjonalnych medalach i monetach podarunkowych. Dysponujemy co najmniej 32 medalami tego typu, przy czym aż 27 wybito w XVII stuleciu, pięć to realizacje z XVIII w. Najczęściej były to wspomniane złote donatywy, niekiedy bite w złocie i srebrze okazjonalne medale historyczne, np. dla upamiętnienia zawarcia pokoju oliwskiego w $1660 \mathrm{r}$. Ostatnie medale z widokami Gdańska pochodzą z 1754 r., dla uczczenia 300-lecia inkorporacji Prus do Korony oraz z 1760 r. na jubileusz 100-lecia pokoju oliwskiego. Pozostałe wielkie miasta Prus Królewskich jedynie sporadycznie zamawiały tego rodzaju dzieła. Złote oraz 
srebrne medale gdańskie z przedstawieniem panoramy uzupełniały kreowany przez literatów obraz panegiryczny dumnego, wielkiego miasta - „laus urbis” czy też „in honorem Magistratus Gedanensis”. Rada Miejska w XVII w. hojnie nagradzała twórców literatury chwalącej Miasto. W XVIII w. słabnące miasto bardziej powściągliwe wydawało środki na cele propagandowe. Po zajęciu Gdańska przez Prusy w 1793 r. tego rodzaju medali już nie wybijano.

\section{BIBLIOGRAPHY}

Arnold, Udo. Studien zur preussischen Historiographie des 16. Jahrhunderts. Bonn: Wellm, 1967.

Biernat, Czesław. "Apogeum handlu gdańskiego w pierwszej połowie XVII wieku." Zapiski Historyczne 36/4 (1971): 145-159.

Bogucka, Maria. Handel zagraniczny Gdańska w pierwszej połowie XVII wieku. Wrocław: Zakład Narodowy im. Ossolińskich, 1970.

Boratyński, Ludwik. "Przyczynek do dziejów pierwszych stosunków handlowych Gdańska z Włochami, a w szczególności z Wenecyą." Rozprawy Wydziału Historyczno-Filozoficznego Akademii Umiejętności 51 (1908): 219-277.

Bujnicki, Kazimierz. "Donatywa.” In S. Orgelbranda Encyklopedja Powszechna, vol. 7, 277-278. Warszawa: Samuel Orgelbrand, 1900.

Bukal, Grzegorz. Fortyfikacje Gdańska i ujścia Wisły 1454-1793. Sopot: Grzegorz Bukal, 2012.

Ciemnołoński, Janusz. “Panoramy Gdańska Antoniego Möllera.” Zeszyty Naukowe Politechniki Gdańskiej. Architektura 10 (1970): 147-156.

Cieślak, Edmund. "Korespondencja Marco Ottobon, wysłannika Wenecji do Polski, z lat 1590-1591." Sprawozdania Gdańskiego Towarzystwa Naukowego 6 (1980): $75-76$.

Drost, Willi. "Das Stadtbild Danzigs in der Kunst." Ostdeutsche Monatshefte 11/4 (1930): 209-217.

Ehrensvärd, Ulla, ed. Cartographica Poloniae 1570-1930. Catalogue of manuscript sources in Swedish collections to the history of Polish territories. Katalog źródet rękopiśmiennych do historii ziem polskich w zbiorach szwedzkich. Warszawa: RetroArt, 2008.

Ehrensvärd, Ulla. "Handgezeichnete Veduten und Pläne in öffentlichen Sammlungen zu Stockholm und Uppsala betreffend Pommern, Mecklenburg, Brandenburg und Westpreußen, ... Lüneburger Beiträge zur Vedutenforschung.” In Lüneburger Beiträge zur Vedutenforschung, edited by Eckhard Jäger, 33-44. Lüneburg: Norddeutsches Kulturwerk, 1983.

Foltz, Max. Geschichte des Danziger Stadthaushalts. Danzig: Kafemann, 1912.

Gloger, Zygmunt. Encyklopedia staropolska ilustrowana, vol. 2. Warszawa: Druk P. Laskauera i W. Babickiego, 1900.

Gosieniecka, Anna. "Dickmann, Idzi (Aegidius).” In Słownik Biograficzny Pomorza Nadwiślańskiego, vol. 1, edited by Stanisław Gierszewski, 329-330. Gdańsk: Wydawnictwo Gdańskie, 1992. 
Groth, Paweł. “Nieznany sztych Idziego Dickmanna z panoramą Gdańska.” Zapiski Historyczne 24/2-3 (1958-1959): 193-196.

Günther, Otto. "Die älteste Sammlung von Danziger Ansichten." Zeitschrift des Westpreussischen Geschichtsvereins 41 (1900): 189-196.

Günther, Otto. “Ein Stückchen Danzig im Jahre 1553.” Mitteilungen des Westpreußischen Geschichtsvereins 11/4 (1912): 62-65.

Haczewska, Bogumiła. "Donatywy pomorskie." In Sztuka XVII wieku w Polsce. Materiały Sesji Stowarzyszenia Historyków Sztuki, Kraków, grudzień 1993, 275-288. Warszawa: Arx Regia, 1994.

Harasimowicz, Jan. "Antoni Möller - malarz, moralista, obywatel." Biuletyn Historii Sztuki 56/3 (1994): 339-358.

Harasimowicz, Jan. “Danziger Maler Anton Möller als Bürger seiner Stadt und eifriger Moralist im Geiste der lutherischen Reformorthodoxie." In Art, religion et société dans l'espace germanique au XVI ${ }^{e}$ siècle, edited by Frank Muller, 77-104. Strasbourg: Presses Universitaires de Strasbourg, 1997.

Harasimowicz, Jan. "Doctrina Doctrinarum. Katechetyczne i społeczno-obyczajowe treści 'Dziesięciu Przykazań” z Pruszcza Gdańskiego.” Porta Aurea. Rocznik Zakładu Historii Sztuki Uniwersytetu Gdańskiego 2 (1993): 55-99.

Hirsch, Theodor. "Ueber den Handelsverkehr Danzigs mit den Italienischen Staaten zu Ende des 16. Jahrhunderts." Preussische Provinzial-Blätter 4 (1847): 97-114.

Idziak, Danuta. Dawny Gdańsk w rycinach XVI-XVIII w. Katalog wystawy Muzeum Pomorskiego w Gdańsku. Gdańsk: Muzeum Pomorskie w Gdańsku, 1969.

Iwanoyko, Eugeniusz. Apoteoza Gdańska. Program ideowy malowideł stropu Wielkiej Sali Rady Ratusza Głównego Miasta. Gdańsk: Zakład Narodowy im. Ossolińskich, 1976.

Jakrzewska-Śnieżko, Zofia. “Antoniego Möllera widok Gdańska z końca XVI wieku.” Libri Gedanenses 6-7 (1975): 5-28.

Jakrzewska-Śnieżko, Zofia. "Architektura i umocnienia obronne Gdańska w 3 ćw. XVI w. na podstawie ryciny F. Hogenberga z 1573 r.” Biuletyn Historii Sztuki 1 (1972): 36-44.

Jakrzewska-Śnieżko, Zofia. Gdańsk w dawnych rycinach. Wrocław: Zakład Narodowy im. Ossolińskich, 1980.

Kizik, Edmund. "Danziger Veduten und Straßenszenen aus dem 18. Jahrhundert." Vana Tallinn 21 (2010): 140-159.

Kizik, Edmund. "Gdański medal jubileuszowy z okazji trzechsetlecia inkorporacji Prus do Polski w 1754 roku." Zapiski Historyczne 77/2 (2012): 79-91.

Kizik, Edmund. "Inkorporacja Prus do Polski i wojna trzynastoletnia w świetle historiografii pruskiej (2 połowa XVI-XVIII w.). U źródeł świadomości historycznej w Prusach Królewskich." In My i oni. Społeczeństwo nowożytnej Rzeczypospolitej wobec państwa, edited by Wojciech Kriegseisen, 75-97. Warszawa: Instytut Historii PAN, 2016.

Kizik, Edmund. “O ubiorach żydowskich i gdańskich na przełomie XVI i XVII wieku. Uwagi w związku z artykułem Jacka Tylickiego.” Biuletyn Historii Sztuki 45/1 (2003): 135-143. 
Kizik, Edmund. "Prezenty w polityce Gdańska w XVII-XVIII wieku." In Prusy i Inflanty między średniowieczem a nowożytnością. Państwo - społeczeństwo - kultura, edited by Bogusław Dybaś and Dariusz Makiłła, 105-116. Toruń: Uniwersytet Mikołaja Kopernika, 2003.

Kizik, Edmund. "Remuneration for Works Dedicated or Donated to the City Council of Gdańsk in the $17^{\text {th }}$ century. Source-based contribution to the history of urban arts sponsorship." Polish Libraries 2 (2014): 167-179.

Kizik, Edmund. "Ubiory gdańskich mieszczek w końcu XVI i w pierwszej połowie XVII wieku." Rocznik Gdański 67-68 (2007-2008): 17-31.

Kizik, Edmund. Wesele, kilka chrztów i pogrzebów. Uroczystości rodzinne w mieście hanzeatyckim od XVI do XVIII wieku. Gdańsk: Officina Ferberiana, 2001.

Kizik, Edmund. "Wynagrodzenia za dzieła dedykowane lub ofiarowane Radzie Miejskiej Gdańska w XVII w. Źródłowy przyczynek do dziejów mecenatu miejskiego.” Rocznik Biblioteki Narodowej 43 (2012): 75-85.

Kloeppel, Otto. Das Stadtbild von Danzig in den drei Jahrhunderten seiner großen Geschichte. Danzig: A. W. Kafemann, 1937.

Kotarski, Edmund. Gdańska poezja okolicznościowa XVII wieku. Gdańsk: Instytut Bałtycki, 1993.

Kozica, Kazimierz and Janusz Pezda. Dantiscum Emporium Totius Europae Celeberrimum. Gdańsk i Bałtyk na mapach, widokach oraz dokumentach ze zbiorów Tomasza Niewodniczańskiego. Katalog wystawy. Gdańsk: Muzeum Historyczne Miasta Gdańska, 2004.

Labuda, Adam S. Malarstwo tablicowe w Gdańsku w 2 poł. XV w. Warszawa: Państwowe Wydawnictwo Naukowe, 1979.

Lengnich, Gottfried. Ius publicum civitatis gedanensis oder der Stadt Danzig Verfassung und Rechte. Edited by Otto Günther. Danzig: Th. Bertling 1900.

Lingenberg, Heinz. „Die baugeschichtliche Entwicklung Danzigs im Spiegel seiner ältesten Veduten (bis zum Anfang des 17. Jahrhunderts) (mit einer Falttafel).” In Lüneburger Beiträge zur Vedutenforschung, edited by Eckhard Jäger, 85-96. Lüneburg: Nordostdeutsches Kulturwerk, 1983.

Meyer, Hans Bernhard. “Danziger Stadtveduten.” Unser Danzig 33/4 (1981): 10-12.

Meyer, Hans. Die Danziger Stadtvedute in ihrer künstlerischen Würdigung. Ein Beitrag zur Geschichte der Vedute. Königsberg in Pr.: Klutke, 1934.

Michalski, Sergiusz. "Gdańsk als auserwählte Christengemeinschaft." In Ars Auro Prior. Studia Ioanni Białostocki Sexagenario Dicata, edited by William S. Heckscher and George Kubler. Warszawa: Państwowe Wydawnictwo Naukowe, 1981.

Mielnik, Magdalena. "Stateczne matrony i cnotliwe panny, czyli 'Księga ubiorów gdańskich’ Antona Möllera w kontekście tradycji ‘Trachtenbüchern.' Quart (2008) issue 3: 20-40.

Mosingiewicz, Anna and Dariusz Kaczor. Portret ponad wszystko. Jacob Wessel i jego wiek. Sztuka Gdańska XVIII wieku. Gdańsk: Muzeum Narodowe w Gdańsku, 2005.

Możejko, Beata. Czynsz gdański w polityce Kazimierza Jagiellończyka i jego synów. Gdańsk: Wydawnictwo Uniwersytetu Gdańskiego, 2004. 
Musiałowski, Adam, ed. Mennice i monety toruńskie 1233/1238-1765. Katalog wystawy. Toruń: Muzeum Okręgowe w Toruniu, 2006.

Musiałowski, Adam. "Panorama miasta na monetach i medalach toruńskich." In Pozaekonomiczne funkcje monet. X Ogólnopolska Sesja Numizmatyczna w Nowej Soli, 103-120. Poznań: Muzeum Miejskie w Nowej Soli, 1995.

Pałubicki, Janusz. Malarze Gdańscy. Malarze, szklarze, rysownicy i rytownicy w okresie nowożytnym $w$ gdańskich materiałach archiwalnych, vol. 1-2. Gdańsk: Muzeum Narodowe w Gdańsku, 2009.

Radziwiłł, Albrycht Stanisław. Pamiętnik o dziejach w Polsce, vol. 2: 1637-1646. Translated and edited by Adam Przyboś and Roman Żelowski. Warszawa: Państwowy Instytut Wydawniczy, 1980.

Rembowska, Irena. "Panorama Gdańska w grafice XVI-XVIII wieku." Zeszyty Naukowe Wydziału Humanistycznego Uniwerystetu Gdańskiego. Historia 1 (1972): 39-55.

Rühle, Siegfried. "Die historischen Medaillen der Stadt Danzig. Ein Beitrag zur Geschichte der Danziger Medaillenkunst und ihrer Künstler." Zeitschrift des Westpreussischen Geschichtsvereins 68 (1928): 243-308.

Schwarz, Friedrich. Danzig im Bilde. Verzeichnis der in der Danziger Stadtbibliothek vorhandenen bildlichen Darstellungen zur Geschichte und Topographie von Danzig und Umgegend. Danzig: A. W. Kafemann, 1913.

Schwarz, Friedrich. Das Deutsche Danzig im Wandel der Zeit in 60 Bildern. Danzig: Paul Rosenberg, 1927.

Simson, Paul. Geschichte der Stadt Danzig, vol. 4. Danzig: A. W. Kafemann, 1918.

Stahr, Maria. Medale polskie i z Polska zwiazane od XVI do XVIII wieku. Katalog zbiorów Muzeum Narodowego w Poznaniu. Poznań: Muzeum Narodowe w Poznaniu, 2008.

Stahr, Maria. Medale Wazów w Polsce 1587-1668. Wrocław: Ossolineum, 1990.

Szczuczko, Witold. "Postanowienia wielkiego przywileju królewskiego z 1457 r." In Historia Elblaga, vol. 2/1: (1466-1626), edited by Andrzej Groth, 12-14. Gdańsk: Marpress, 1996.

Szczuczko, Witold. Przywileje królów polskich dla Elblaga. Gdańsk: Wydawnictwo Morskie, 1991.

Talbierska, Jolanta, ed. Gdańsk dla Rzeczypospolitej w służbie Króla i Kościoła. Gdańsk: Muzeum Historyczne Miasta Gdańska, 2004.

Tielhof, Milja van. The 'Mother of All Trades'. The Baltic Grain Trade in Amsterdam from the Late $16^{\text {th }}$ to the Early $19^{\text {th }}$ Century. Leiden, Boston, Köln: Brill, 2002.

Toeppen, Max, ed. Acten der Ständetage Preussens unter der Herrschaft des Deutschen Ordens, vol. 4. Leipzig: Duncker \& Humblot, 1884.

Tylicki, Jacek. "Donatywa medalowa z perspektywicznym widokiem Gdańska." In Herman Han. Mistrz światła i nokturnu. Narodziny baroku w malarstwie dawnej Rzeczpospolitej, edited by Marcin Osowski, 56-73. Pelplin: Bernardinum, 2008.

Tylicki, Jacek. "O historii sztuki i numizmatyce, czyli kto zaprojektował niektóre gdańskie donatywy Zygmunta III.” Biuletyn Numizmatyczny (2009) issue 1:27-38.

Tylicki, Jacek. "Obraz 'Alegoria cnoty małżeńskiej. Klucz do drugiego oblicza sztuki Hermanna Hana.” Biuletyn Historii Sztuki 59/1-2 (1997): 38-59. 
Tylicki, Jacek. Rysunek gdański ostatniej ćwierci XVI i pierwszej połowy XVII wieku. Torun: Wydawnictwo Uniwersytetu Mikołaja Kopernika, 2005.

Więcek, Adam. Sebastian Dadler. Medalier gdański XVII wieku. Gdańsk: Gdańskie Towarzystwo Naukowe, 1962.

Wüthrich, Lucas Heinrich. Das druckgraphische Werk von Matthäus Merian, vol. 1-2. Basel: Bärenreiter, 1966.

Wüthrich, Lucas Heinrich. Das druckgraphische Werk von Matthäus Merian, vol. 4. Hamburg: Hoffmann und Campe, 1996.

Zarębska, Teresa. Przebudowa Gdańska w jego złotym wieku. Warszawa: Politechnika Warszawska, 1998.

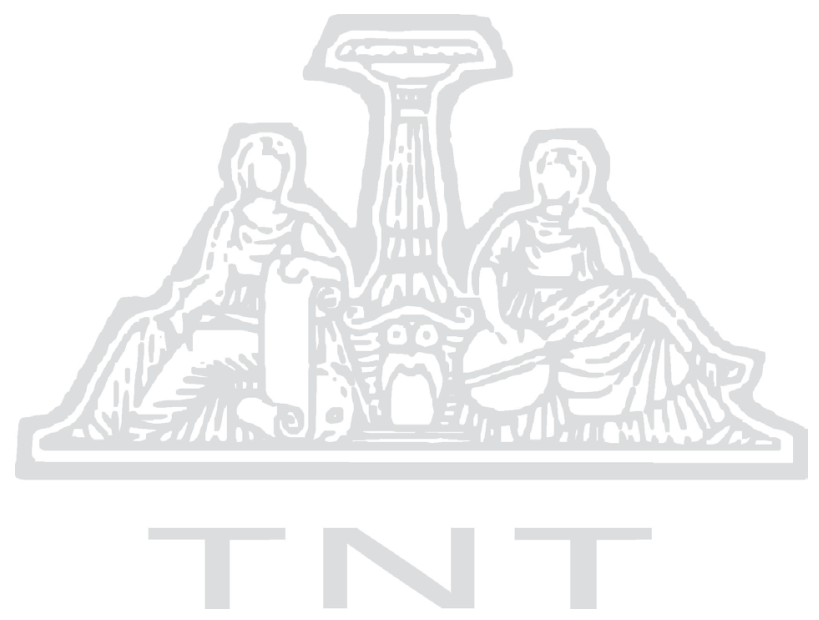

